\title{
OCCUPATIONAL EXPOSURE TO LOCALIZED VIBRATIONS USING PORTABLE MECHANICAL BRUSH CUTTER IN COFFEE CROP
}

\author{
Geraldo Gomes de Oliveira Júnior ${ }^{1}$, Adriano Bortolotti da Silva² ${ }^{2}$ Irlon de Ângelo da Cunha ${ }^{3}$, \\ Lucas Eduardo de Oliveira Aparecido ${ }^{4}$, Paulo Henrique de Siqueira Sabino ${ }^{5}$
}

(Received: March 19, 2019; accepted: April 29, 2019)

\begin{abstract}
The use of portable brush cutter may expose workers to localized vibrations, from the transfer of mechanical vibration of the tool to the operator's hands and arms. With this in mind, the objective in this study was to quantify the levels of occupational vibration transmitted to the hands and arms of the portable brush cutter operators under routine working conditions in the coffee crop. The vibration levels transmitted to the operator's hands were measured during activity with portable brush cutters. The experimental design was completely randomized (CRD) in a factorial scheme (2x 2$)$ combined with two types of grip (Circular cable (CC) and double grip handle (DGH) with two types of tip cutting blades (2TB and 3TB). The data acquisition occurred from the use of the vibration meter SV 103, SVANTEK with triaxial accelerometer, installed on each of the worker's hand at the contact point with the tool. The results demonstrated that the $2.5 \mathrm{~ms}^{-2}$ action level determined by NR 09 and NHO 10 was exceeded under all conditions of the present study. The highest accelerations were quantified in the operation of the brush cutter equipment with $\mathrm{CC}$, reaching the daily exposure limit of $5 \mathrm{~ms}^{-2}$ allowed for an 8-hour of working day. The resulting acceleration of the DGH equipment was on average $37.45 \%$ lower than the operation with the CC equipment. The results bring indicatives of occupational advantages in the selection of these types of accessories for brush cutters, in order to mitigate the effects of exposure to HAV in extended use situations.
\end{abstract}

Index terms: Coffee crop, hands and arms vibration, workplace safety.

\section{EXPOSIÇÃO OCUPACIONAL À VIBRAÇÕES LOCALIZADAS UTILIZANDO ROÇADEIRA MECÂNICA PORTATIL NA CULTURA DO CAFEEIRO}

\begin{abstract}
RESUMO: A utilização de roçadeira mecânica portátil pode expor trabalhadores à vibrações localizadas, a partir da transferência da vibração mecânica da ferramenta para as mãos e braços do operador. Neste sentido, objetivou-se no presente estudo quantificar os níveis de vibração ocupacional transmitidos às mãos e braços dos operadores de roçadeiras portáteis, em condições rotineiras de trabalho na cultura do cafeeiro. Os níveis de vibração transmitidos às mãos do operador foram medidos durante atividade com as roçadeiras portáteis. O delineamento experimental utilizado foi o inteiramente casualizado (DIC) em esquema fatorial ( 2 x 2), sendo combinados dois tipos de empunhadura (Cabo Circular CC e Empunhadura Dupla Guidão EDG) com dois tipos de lâminas de corte (2P e 3P). A aquisição dos dados ocorreu a partir da utilização do medidor de vibração SV 103, Svantek com acelerômetro triaxial, instalado em cada uma das mãos do trabalhador no ponto de contato com a ferramenta. Os resultados demonstraram que o nível de ação 2,5 ms-2 determinado pela NR 09 e NHO 10 foi ultrapassado em todas as condições do presente estudo. As maiores acelerações foram quantificadas na operação do equipamento roçadeira com $\mathrm{CC}$, atingindo o limite de exposição diária de $5 \mathrm{~ms}^{-2}$ permitido para uma jornada de trabalho de 8 horas. A aceleração resultante do equipamento com EDG foi em média 37,45\% inferior à operação do equipamento com CC. Os resultados obtidos trazem indicativos de vantagens ocupacionais na seleção desses tipos de acessórios para as roçadeiras, de modo a mitigar os efeitos da exposição à VMB em situações de uso prolongado.
\end{abstract}

Termos para indexação: Cafeicultura, segurança do trabalho, vibração de mãos e braços.

\section{INTRODUCTION}

The Coffee cultivation is one of the main Brazilian agricultural crops (HAJJAR et al., 2019; REICHAMAN, 2018) and in the recent years has undergone significant changes, especially in the mechanization of cultural practices, which previously were traditionally performed manually
(CUNHA; SILVA; DIAS, 2016; SILVA et al., 2018). Mechanization is a useful tool so that the coffee growers can improve the efficiency of their activities, productivity and reduction of production costs (SANTINATO et al., 2014; CUNHA et al., 2016).

In the south of Minas Gerais state the use of motorized portable mechanical equipment has

\footnotetext{
${ }^{1}$ Intituto Federal de Educação, Ciência e Tecnologia do Sul de Minas/IFSULDEMINAS - Campus Muzambinho - Estrada de Muzambinho, Km 35 - Cx. P. 02 - 37.890-000 - Muzambinho - MG - geraldo.junior@muz.ifsuldeminas.edu.br

${ }^{2,5}$ Universidade José do Rosário Vellano/UNIFENAS - Campus Alfenas - Rodovia MG 179 - Cx. P. 23 - 37.132-440 - Alfenas - MG adriano.silva@unifenas.br,paulo.sabino@unifenas.br

${ }^{3}$ Fundação Jorge Duprat Figueiredo de Segurança e Medicina do Trabalho - Fundacentro, Centro Técnico Nacional CTN Rua Capote Valente, 710 - 05.409-002 - São Paulo - SP - irlon@fundacentro.gov.br

${ }^{4}$ Instituto Federal de Educação, Ciência e Tecnologia de Mato Grosso do Sul - Campus Naviraí - Rua Hilda, 203 - Bairro Boa Vista 79.950-000 - Naviraí - MS - lucas-aparecido@outlook.com
} 
increased significantly, being used in the activities of coffee mowing, pruning and harvesting. The use of these equipments brings higher yields in the agricultural operations, however, these activities can imply in the occupational exposure of the workers to localized vibrations, from the transfer of the mechanical vibration of the tool to the hands and arms of the operator. Poletto, Santos and Poletto (2015), affirmed that noise and vibration are two occupational risk agents present in the activity of the brush cutter operator.

Although occupational vibration is not as studied as other environmental hazards, their presence in the workplace is very frequent. Worldwide, the number of workers exposed to vibration by the use of hand tools is expressive (SINGH; KHAN, 2014). The occupational exposure to hands and arms vibration (HAV) can cause damage to workers' health by presenting vascular, neurological, osteoarticular and muscular symptoms that characterize Hand and Arms Vibration Syndrome (HAVS) (HEAVER et al., 2011; FUNDACENTRO, 2013; CAMPBELL; JANKO; HACKER, 2017; CALVO et al., 2018; PATIL, 2018; KUPPA; LAL, 2019).

In the Brazilian agriculture, scientific studies dealing with hand and arm vibration levels (HAV) in workers operating portable mechanical equipment are scarce. However, several studies carried out in other countries have demonstrated the importance of this issue given its relevance to the protection of workers' health (ÇAKMAK et al., 2011; HAO; EAN; RIPIN, 2011; AIELLO et al., 2012; WÓJCIK, 2015; AZMIR; YAHYA, 2017; ROMANO et al., 2017; BERNADI et al., 2018; CALVO et al., 2018). Heaver et al (2011) stated that the early recognition of exposure to vibration is of fundamental importance to promote risk management and prevent the occurrence of health damage of exposed workers.

In Brazil, the Regulatory Standard NR 09 from the Ministry of Labor and the Occupational Hygiene Standard NHO 10 from Jorge Duprat Figueiredo Foundation for Safety and Occupational Medicine (FUNDACENTRO) defined the value of $2.5 \mathrm{~ms}^{-2}$ as action level and $5.0 \mathrm{~ms}^{-2}$ as Exposure Limit for occupational exposure to HAV. This exposure limit is used in the Regulatory Standard NR 15 as a reference for the characterization of unhealthiness (BRASIL, 2014; FUNDACENTRO, 2013). It is noteworthy that these levels are the same recommended by the international standards American Conference of Governmental Industrial Hygienists (ACGIH) and by the European directive, DIRECTIVE 2002 (ACGIH, 2018; EUROPEAN DIRECTIVE, 2002).
The brush cutters commercially available and in use by workers in the southern of Minas Gerais coffee plantations have basically two mechanisms for coupling the hand with the tool, called circular cable (CC) and double grip handle (DGH). Considering that the occupational exposure to localized vibrations necessarily occurs from the worker's contact with the tool and consequently transfer of the mechanical vibration to the hands and arms of the operator. The mechanism for coupling the hands with the tool, along with the cutting blades used, can influence the HAV levels received by the operator.

Therefore, the importance and necessity of carrying out studies that quantify the levels of occupational vibration in portable mechanical brush cutters under normal and routine working conditions is evidenced. And so, compare them with the action level and the exposure limit set by the current standards NR 09, NR 15 and NHO 10, in order to support preventive, organizational and protective actions to avoid damage to the workers' health and possible negative effects on production costs.

Thus, the objective in this study was to quantify the levels of occupational vibration transmitted to hands and arms of the portable mechanical brush cutter operators, under routine working conditions in the coffee crop.

\section{MATERIAL AND METHODS}

The present study was carried out at the Federal Institute of Education, Science and Technology of the Southern of Minas Gerais, IFSULDEMINAS, Campus Muzambinho - MG (Figure 1).

The mowing activity was carried out from December 2018 to January 2019 in the plot called roasting cultivated with (Coffea arabica), Catucaí Yellow, 3 years old, planted at a spacing of 3.5 x $0.7 \mathrm{~m}$, located at $1000 \mathrm{~m}$ of altitude. Panicum maximum was the predominant spontaneous grass vegetation in the area, with a mean height of 0.85 m (Figure 2).

The vibration levels transmitted to the operator's hands were measured in two new portable mechanical brush cutters, one of which has a hand-held coupling with the tool, called a double grip handle (DGH) and another circular cable (CC) (Figure 3A and B).

Both brush cutters have an internal combustion engine of two-stroke, $0.95 \mathrm{~kW}$ power, $2800 \mathrm{rpm}$ idle mode, $10,500 \mathrm{rpm}$ limiting rotation, the tube axis of $1.5 \mathrm{~m}$, commercially available and in use by the coffee-growing workers of the southern of Minas Gerais. 

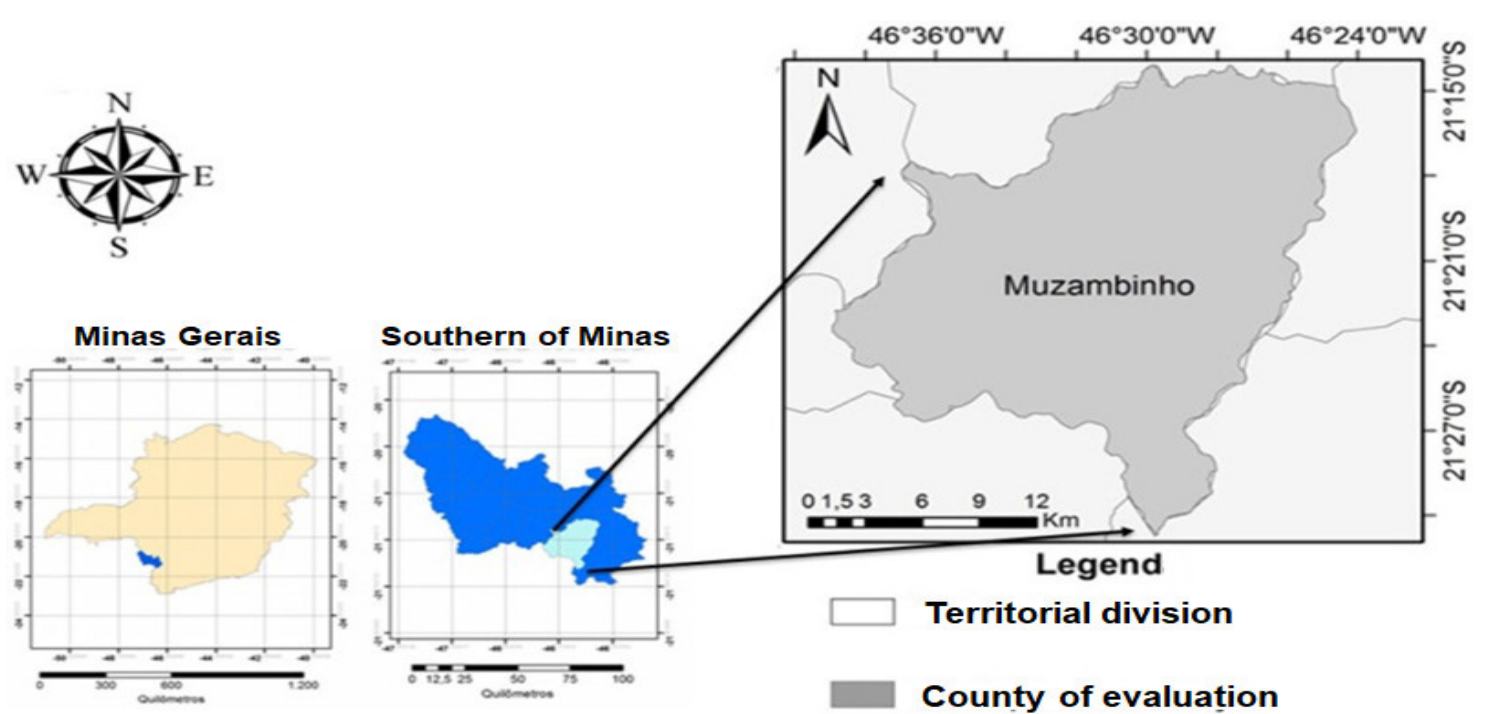

FIGURE 1 - Geographical location of the study site.

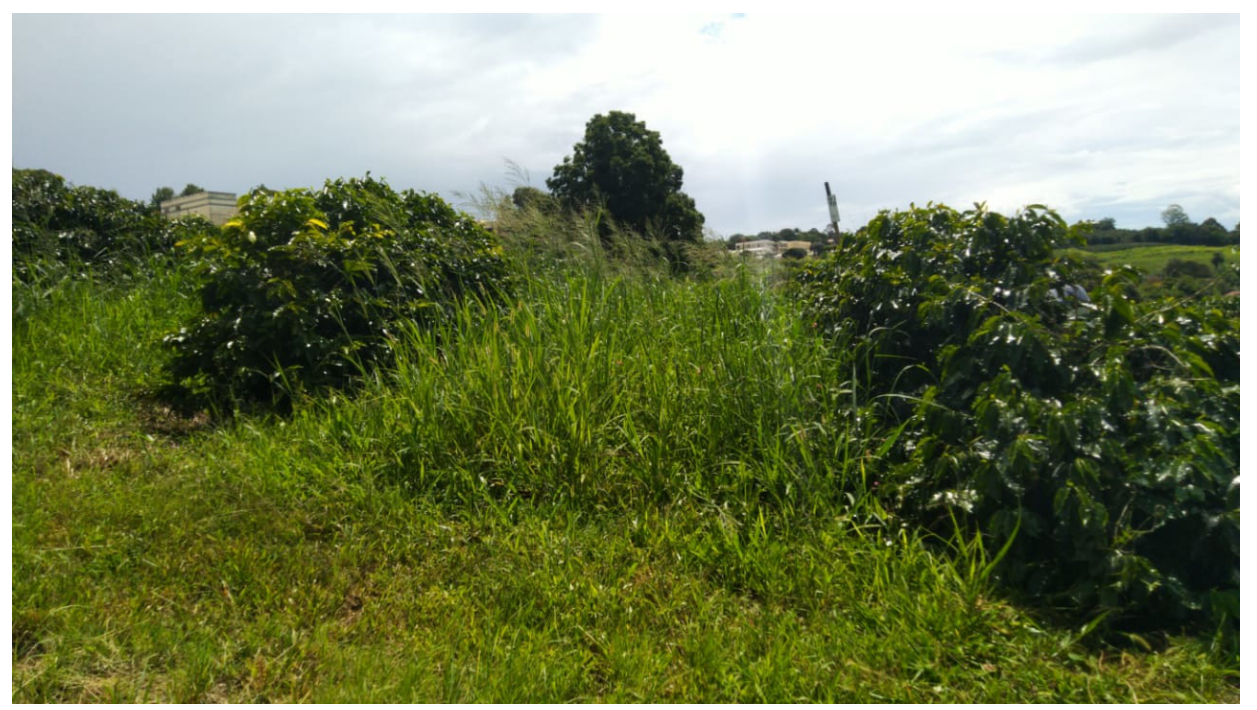

FIGURE 2 - Spontaneous grass vegetation (Panicum maximum) in the experiment area.

Two (2TB) and three-tip (3TB) cutting blades were used in both DGH and CC grip equipments (Figure 3C and D).

Before starting the collect of the vibration levels, the two brush cutters were turned on and operated for about 15 minutes without cutting, so that stable conditions were reached, with the rotation at idle mode and full rotation being checked, using the rotation indicator equipment EDT 9 Stihl (Figure 4).

The mowing activity was performed by an experienced operator, right-handed, age 29 years old and with the following anthropometric characteristics: height $1.76 \mathrm{~m}$, weight $69.9 \mathrm{Kg}$, total length of upper limbs (arm, forearm and hands) of $0.83 \mathrm{~m}$. The data collection began after the approval of the Ethics Committee in Human Research (ECHR), process $n^{\circ}$ 02216818.1.0000.8158 and signing the Free and Clarified Consent Term (FCCT) by the operator.

The acquisition of the vibration data was performed by the vibration meter SV 103, Svantek serial number 56895, calibrated with the certificate from the Brazilian RBC Calibration Network, taking into account the weighting requirements (Wh) and the characteristics provided in the international standards ISO 8041 (2005), ISO 5349-1 (2001) and national standard NHO 10. 

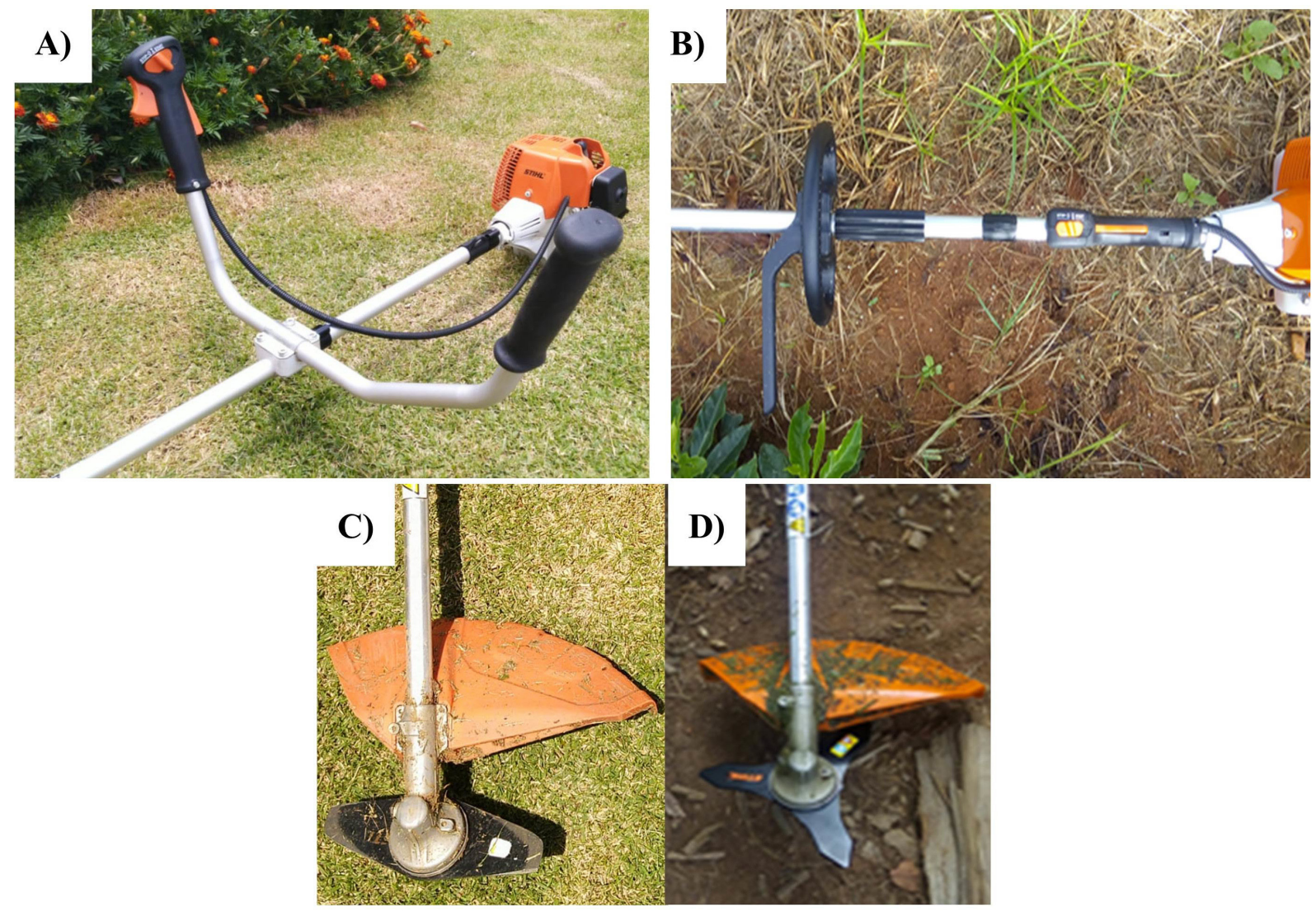

FIGURE 3 - Double grip handle DGH (A), Circular cable grip CC (B); Cutting system: two-tip blades (C); and three-tip blades (D).

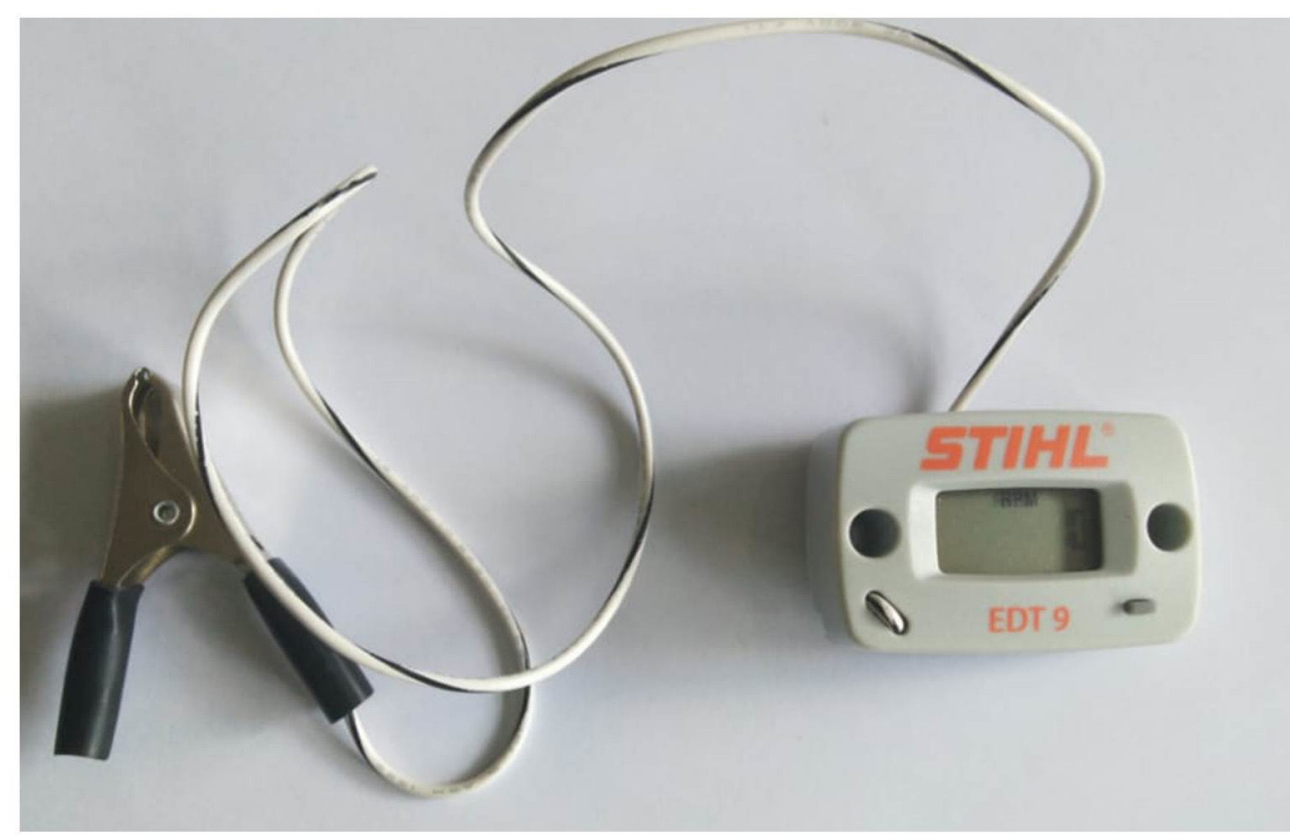

FIGURE 4 - Rotation indicator equipment EDT 9 Stihl. 
The measuring set is integrated with the SV 107 Micro Electro-Mechanical Systems (MEMS) triaxial accelerometer with sensitivity of $( \pm 5 \%)$ $0.661 \mathrm{mV} / \mathrm{ms}^{2}$. The orthogonal axes " $\mathrm{x}$ ", " $\mathrm{y}$ " and " $z$ " were simultaneously evaluated (Figure 5).

The transducers were set up in each of the operator's hands, and at the hands coupling point with the tool (Figure 6). The operator was instructed to use the equipment within the normal working characteristics in terms of speed and displacements undertaken, maintaining the gripping force and drive naturally employed in this activity. The resulting acceleration of the normalized exposure was determined for both the right hand (Acceleration Hand) and the left hand of the worker.
The experimental design was completely randomized (CRD) in a factorial scheme $(2 \times 2)$, combined with two types of grips (CC and DGH) and two types of tip cutting blades (2TB and 3TB), totaling 4 treatments with 6 replicates. The treatments consisted of Circular Cable with two tip cutting blades (CC - 2TB); Circular Cable with three - tip cutting blades (CC - 3TB); Double Grip Handle with two - tip cutting blades (DGH - 2TB) and Double Grip Handle with three tip cutting blades (DGH - 3TB).

After the evaluations, the data collected in a frequency band of $1 / 3$ octave from 0.8 to $1600 \mathrm{~Hz}$ were downloaded and processed using supervisory software version 1.12 .
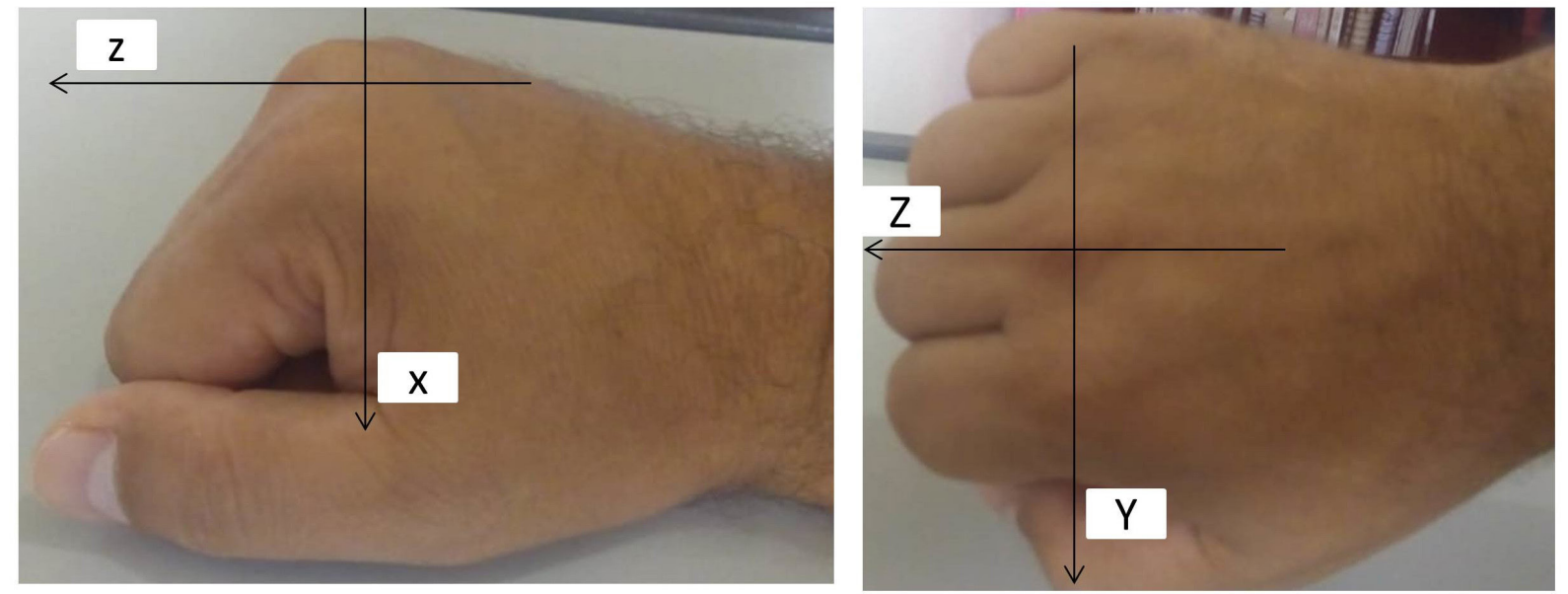

FIGURE 5 - Direction of the Orthogonal Axes "x", “y” and "z" according to NHO 10.

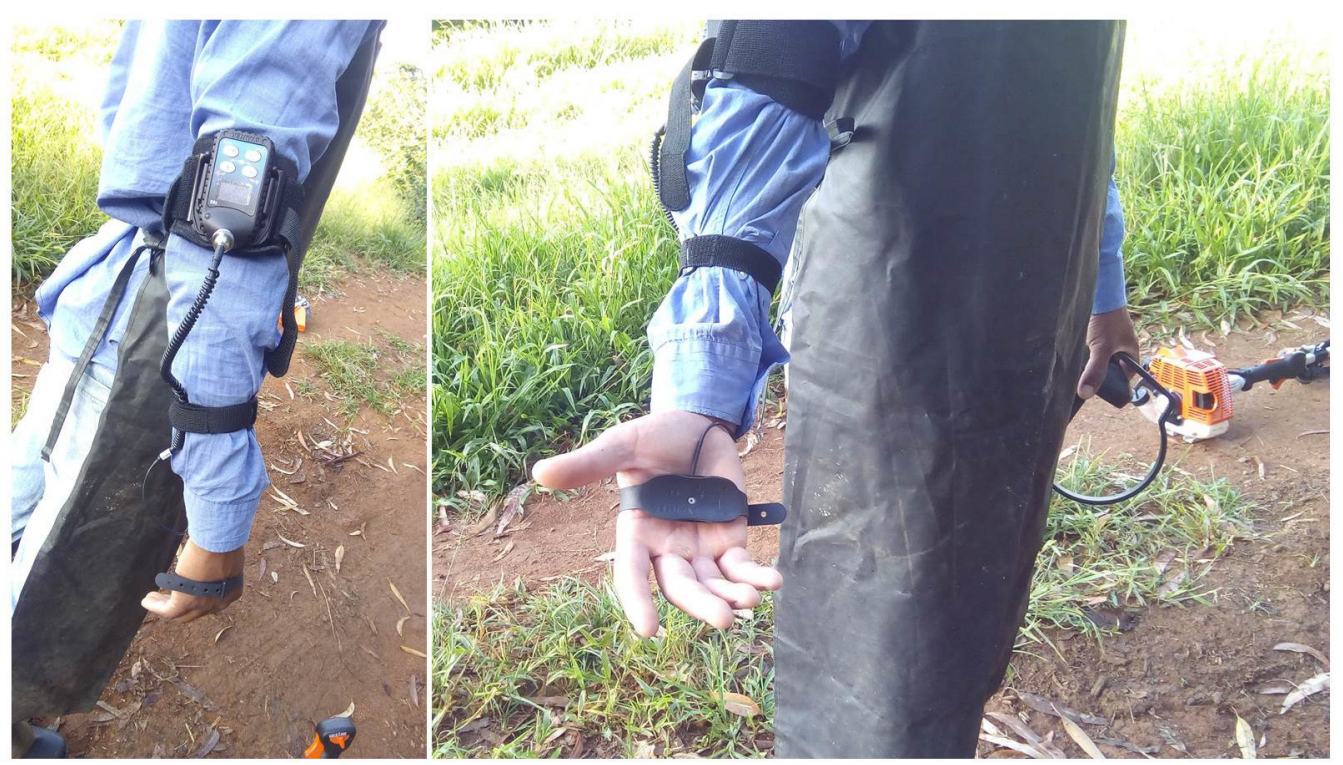

FIGURE 6 - Assembly of the equipment in the operator's hand. 
As indicated by FUNDACENTRO (2013), the accelerations in the three perpendicular directions, " $x$ ", " $y$ " and " $z$ " were determined and the resulting mean acceleration value (rma) was obtained by summing the root of the squares of the mean accelerations expressed in $\mathrm{ms}^{-2}$ (Equation 1) according to NHO 10 and ISO 5349-1 (2001):

$$
r m a=\sqrt{\left(f_{x} a m_{x}\right)^{2}+\left(f_{y} a m_{y}\right)^{2}+\left(f_{z} a m_{z}\right)^{2}} \quad\left[m^{-2}\right]
$$

Where:

$\mathrm{ma}_{\mathrm{j}}-$ mean acceleration; considered.

$\mathrm{f}_{\mathrm{j}}$ - multiplication factor due to the axis

For the purposes of comparison with the action level and the exposure limit quoted in NR 09, NR 15 and NHO 10, the acceleration resulting of normalized exposure (arne) was determined and expressed in $\mathrm{ms}^{-2}$ (Equation 2), according to the NHO 10 (2013) standards. This metric (arne) is equivalent to the acceleration $\mathrm{a}_{\mathrm{hv}} \mathrm{A}(8)$ expressed in ISO 5349-1 (2001):

$$
\text { arne }=\operatorname{are} \sqrt{\frac{T}{T_{0}}} \quad\left[m s^{-2}\right]
$$

Where:

are - acceleration resulting of exposure;

$\mathrm{T}$ - daily working time in hours, expressed in hours or minutes;

$\mathrm{T}_{0}-8$ hours or 480 minutes.

The arne values obtained were submitted to analysis of variance. In cases where the value of the F test was significant, Tukey tests were performed at the $5 \%$ level of significance. For that purpose, we used the statistical software "SISVAR" (FERREIRA, 2011).

\section{RESULTS AND DISCUSSION}

There was no interaction between the study factors, types of Grips (CC and $\mathrm{DGH}$ ) and tip cutting blades (2TB and 3TB), both for the right hand $(\mathrm{F}=0.15, \mathrm{p} \geq 0.05)$ and for the left hand $(\mathrm{F}=$ $0.14, \mathrm{p} \geq 0.05$ ). The factors had a significant effect in an isolated form (Table 1).

The acceleration levels resulting of normalized exposure (arne) for hand and arm vibration (HAV), due to the use of portable brush cutters in the coffee crop can be observed in Figure 7. For all the operating conditions evaluated, the action level of $2.5 \mathrm{~ms}^{-2}$ determined by NR 09 and NHO 10 was exceeded. The results showed significant differences for the vibration levels transmitted to the operator's hands between the use of the brush cutter with CC and DGH $(p \leq 0.05)$ (Figure 7). The greatest accelerations were quantified in the brush cutter operation with $\mathrm{CC}$, both in the right hand and left hand (Figure 7A and $\mathrm{C}$ ).

During the operation of the $\mathrm{CC}$ equipment, the daily exposure limit of $5 \mathrm{~ms}^{-2}$ allowed for an 8-hour working day has been reached in at least one hand. To the right hand the acceleration was $4.5 \mathrm{~ms}^{-2}( \pm 0.61)$ and for the left hand (the support hand) $5.0 \mathrm{~ms}^{-2}( \pm 0.30)$ (Figure 7A and C). Therefore, during the mowing activity with $\mathrm{CC}$ of the present study the maximum working time allowed will be 8 hours in accordance with current legislation, since to operate the equipment the worker needs to hold it with both hands and in the left hand the exposure limit has been reached according to NR 15 and NHO 10 (BRASIL, 2014; FUNDACENTRO, 2013).

It is noteworthy that the exposure limit for the purposes of rule NHO 10 represents conditions under which it is believed that most workers can be exposed repeatedly, without suffering adverse effects to the hand-arm system that may result in damage to the worker's health. However, due to variations in the individual susceptibility of each worker, the exposure limit should not be considered as the definitive dividing line between safe and dangerous levels (ACGIH, 2018).

The results evidenced that the operation of the brush cutter equipment with DGH showed levels of HAV, lower than the use of the equipment with $\mathrm{CC}$ for all the conditions of the present study. On average, the acceleration resulting from normalized exposure (arne) of the DGH equipment was $37.45 \%$ lower than the operation of the $\mathrm{CC}$ equipment, thus showing indicatives of occupational advantages in mitigating the exposure to physical risk vibration in situations of prolonged use.

However, the levels of HAV $2.9 \mathrm{~ms}^{-2}( \pm 0.17)$ and $3.0 \mathrm{~ms}^{-2}( \pm 0.37)$ quantified in the operation of the DGH equipment deserve attention, since they exceed the level of action (arne) of $2.5 \mathrm{~ms}^{-2}$ determined in NR 09 and NHO 10. According to NHO 10, the vibration levels between 2.5 and $5.0 \mathrm{~ms}^{-2}$ exceed the action level and enter the region of uncertainty (FUNDACENTRO, 2013). Performing the quantification of vibration under normal and routine working conditions becomes important in order to acquire specific values avoiding errors in personal judgment (CALVO et al., 2018). 
TABLE 1 - Analysis of variance (ANOVA) in the vibration levels, between the use of the coupling systems of the worker's hands with the tool (Grips) and cutting blades

\begin{tabular}{|c|c|c|c|c|c|}
\hline \multicolumn{6}{|c|}{ Right Hand (RH) } \\
\hline Variation Factor & $\mathrm{DF}$ & SSQ & MSQ & $\mathrm{Fc}$ & $\operatorname{Pr}>\mathrm{Fc}^{(1)}$ \\
\hline Grip & 1 & 13.02 & 13.02 & 135.16 & 0.00 \\
\hline Blade & 1 & 3.46 & 3.46 & 35.96 & 0.00 \\
\hline Grip*Blade & 1 & 0.21 & 0.21 & 2.24 & 0.15 \\
\hline Error & 20 & 1.92 & 0.09 & - & - \\
\hline Total & 23 & 18.63 & - & - & - \\
\hline $\mathrm{CV}(\%)^{(2)}$ & & & 8.18 & & \\
\hline \multicolumn{6}{|c|}{ Left Hand (LH) } \\
\hline Variation Factor & $\mathrm{DF}$ & SSQ & MSQ & $\mathrm{Fc}$ & $\mathrm{Pr}>\mathrm{Fc}$ \\
\hline Grip & 1 & 26.64 & 26.64 & 461.97 & 0.00 \\
\hline Blade & 1 & 0.02 & 0.02 & 0.40 & 0.53 \\
\hline Grip*Blade & 1 & 0.13 & 0.13 & 2.36 & 0.14 \\
\hline Error & 20 & 1.15 & 0.05 & - & - \\
\hline Total & 23 & 27.96 & - & - & - \\
\hline CV (\%) & & & 6.04 & & \\
\hline
\end{tabular}

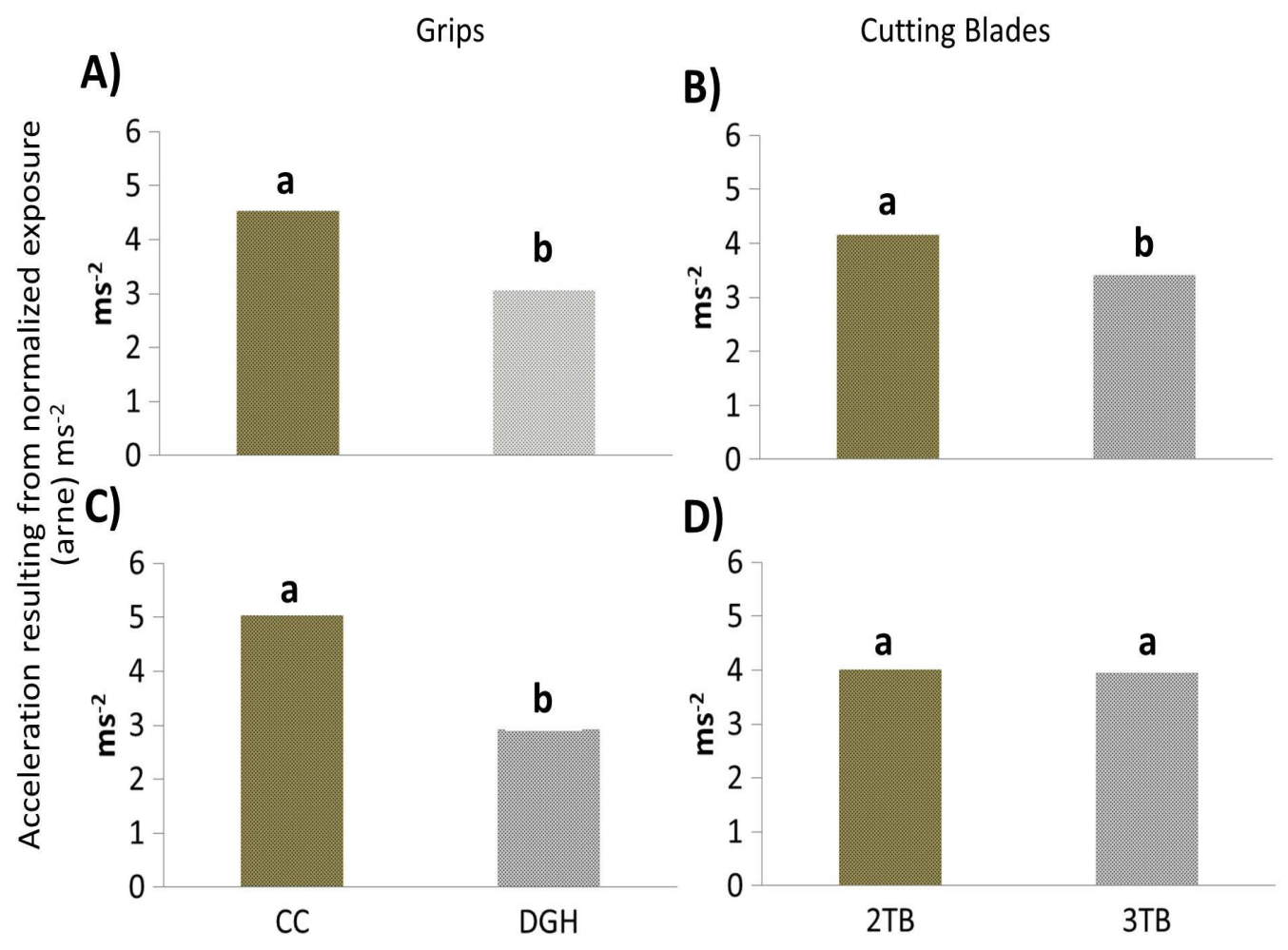

FIGURE 7 - Hands and arms' vibration in the operation of the equipment with circular cable (CC) and double grip handle (DGH) for the right and left hand. The mean vibration levels between the CC and DGH Grips were compared by the Tukey test at the 95\% confidence level. Legend: Right hand (A and B), Left hand (C and D). 
In addition to the vibration, it was observed that during the operation of the DGH equipment, the worker remained with the trunk aligned providing an ergonomically more adequate posture. Ferrary et al. (2018) stated that recent studies have demonstrated a direct relationship between the inadequate use of the brush cutter equipment and possible muscle and skeletal disorders.

There were significant differences for the vibration levels found in the operator's acceleration hand (right hand), between the use of two (2TB) and three $(3 \mathrm{~TB})$ tip blades $(\mathrm{p} \leq 0.05)$ (Figure 7B). In the left hand, no statistical differences were verified (Figure 7D).

In the right hand the use of $2 \mathrm{~TB}$ presented accelerations superior to the use of 3TB (Figure 7B). It is important to reiterate that in the present study we used new brush cutters and new cutting blades. Unbalanced cutting blades, as well as the wear and the lack of maintenance of the brush cutter equipment can contribute to increase the levels of vibration transmitted by the operator's hand. Schutzer (2018) reports that unbalanced and non-sharp blades can amplify the vibration transmitted to the Grip of the cutter.

According to NHO 10, the level of vibration generated by tools that have vibratory characteristics depends on the conditions of use and conservation (FUNDACENTRO, 2013). Still according to FUNDACENTRO (2013), the operator should be advised to communicate his superior whenever he observes abnormal levels of vibration during the use of the work tools.

The mean acceleration spectra quantified on the $\mathrm{Xh}, \mathrm{Yh}$ and $\mathrm{Zh}$ axes were illustrated in Figure 8.

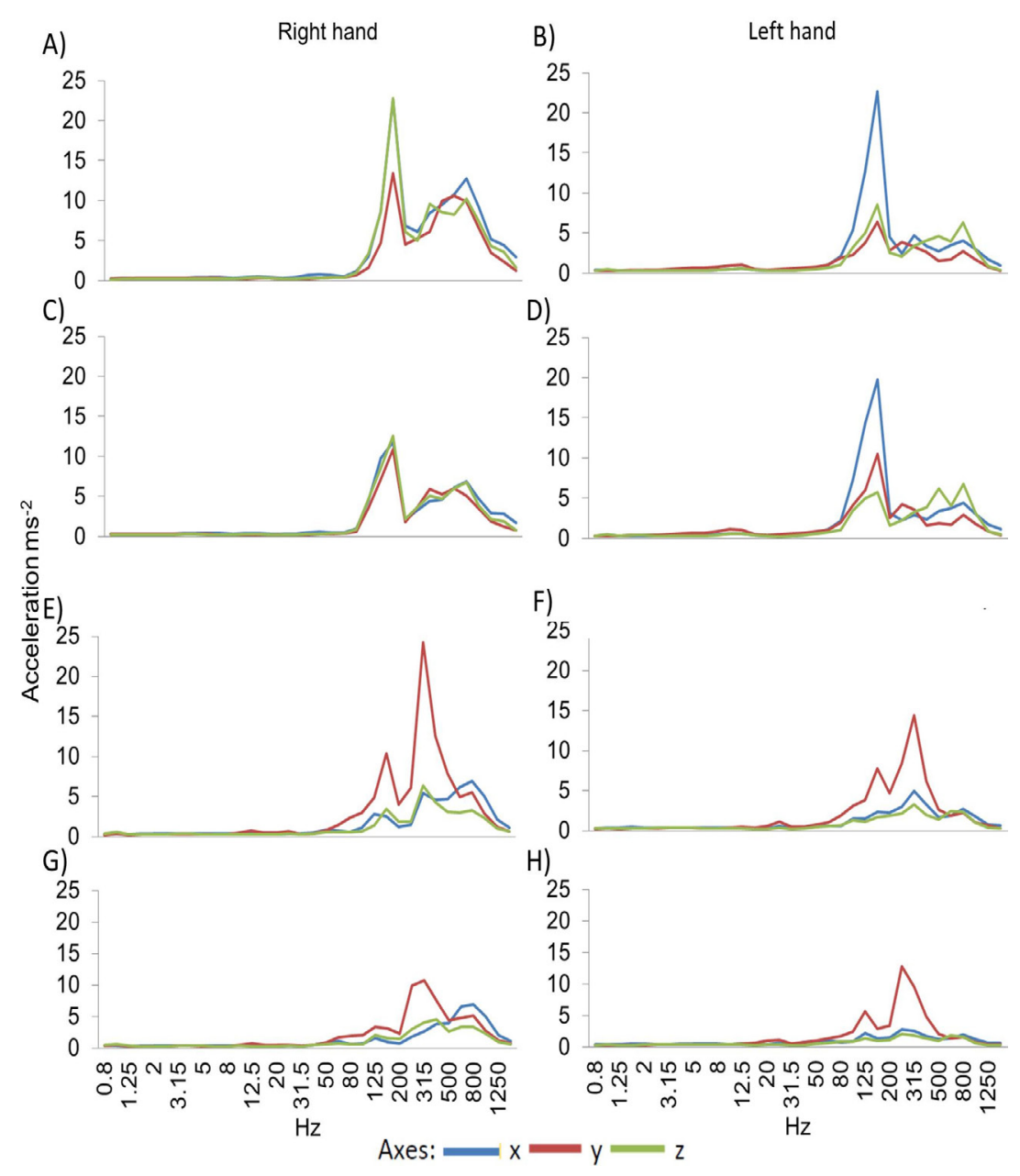

FIGURE 8 - Average acceleration spectrum for the $\mathrm{Xh}$, $\mathrm{Yh}$ and $\mathrm{Zh}$ axes with circular cable (CC) and Double Grip Handle (DGH) using two (2TB) and three (3TB) tip blades. Circular Cable with Two-Tip Blades CC-2TB (A and B), Circular Cable with Three-Tip Blades CC-3TB (C and D), Double Grip Handle with Two-Tip Blades DGH3TB (E and F), Double Grip Handle with Three-Tip blades DGH-3TB (G and H). 
In the $\mathrm{CC}$ equipment the highest acceleration peaks occurred at the $160 \mathrm{~Hz}$ frequency, for the $\mathrm{X}$ axis with a magnitude of $22.6 \mathrm{~ms}^{-2}$ for both the right hand and the left hand and the $\mathrm{Z}$ axis with $22.7 \mathrm{~ms}^{-2}$ at right hand when using CC-2TB (Figure 8A and B). For DGH, the highest acceleration peaks were recorded at the $315 \mathrm{~Hz}$ frequency on the $\mathrm{Y}$ axis, with $24.2 \mathrm{~ms}^{-2}$ for the right hand and $14.3 \mathrm{~ms}^{-2}$ on the left hand using DGH-2TB (Figure 8E and F). Bernardi et al (2018), performing a study on occupational vibration in the use of brush cutters in green areas, also used equipment with double Grip and observed the greatest accelerations in the $\mathrm{Y}$ axis, differing from the present study in frequency and peak magnitude.

The analysis of the frequency bands of one third of the octave did not present high values of acceleration at the low frequencies in the vibration signals (Figure 8). The low frequency accelerations, especially those between 8 and $16 \mathrm{~Hz}$, are prioritized by ISO 5349-1. The human body naturally has vibration and when this external frequency coincides with the natural frequency of the body there is a resonance and amplification of the vibration. Therefore, the acceleration at low frequencies is considered more damaging and harmful to workers' health (HAO; EAN; RIPIN, 2011).

Therefore, workers operating the brush cutter equipment in the coffee crop should be supervised and instructed on the exposure risk to vibration. Azmir and Yahya (2017) stated that providing information, training and monitoring the worker's health is of fundamental importance to mitigate the exposure risk to hand and arm vibration when using brush cutters.

\section{CONCLUSIONS}

The level of action $2.5 \mathrm{~ms}^{-2}$ determined by NR 09 and NHO 10 has exceeded under all conditions of the present study and preventive measures should be taken to periodic monitoring of exposure, information to workers, health surveillance focused on the effects of exposure to vibration, and search to reduce exposure to vibration.

The daily exposure limit of $5 \mathrm{~ms}^{-2}$ was reached only with the use of brush cutters with CC. Blades with tips (3TB) showed lower vibration to the right hand. The resulting acceleration of the DGH equipment was on average $37.45 \%$ lower than the operation of the $\mathrm{CC}$ equipment, thus presenting indicative of occupational advantages in situations of prolonged use.

\section{ACKNOWLEDGEMENTS}

We would like to thank the Federal Institute of Education, Science and Technology of the South of Minas (IFSULDEMINAS), the company Almont do Brazil and the Jorge Duprat Figueiredo Foundation for Safety and Occupational Medicine (FUNDACENTRO) for their support in carrying out this study.

\section{REFERENCES}

AIELLO, B. et al. Real time assessment of handarm vibration system based on capacitive MEMS accelerometers. Computers and Eletronics in Agriculture, Netherlands, v. 85, p. 45-52, 2012.

AZMIR, N.A.; YAHYA, M.N. Prevalence of Handtransmitted Vibration Exposure among Grass-cutting Workers using Objective and Subjective Measures. IOP Conference Series: Materials Science and Engineering, United Kingdom, v.166, p. 1-7, 2017.

BERNARDI, B. et al. Occupational risk related to vibrations using a brush cutter for green area management. Annais of Agricultural and Environmental Medicine, Poland, v. 25, n ${ }^{\circ}$ 2, p. 255 - 258, 2018.

BRASIL. Ministério do Trabalho e Emprego. Portaria $n^{\circ} 1297$ de 13 de Agosto de 2014. Aprova o Anexo I - Vibração da Norma Regulamentadora $n^{0} 9$ Programa de Prevenção de Riscos Ambientais (PPRA), altera o anexo 8 - Vibração da Norma Regulamentadora $n^{\circ} 15$ - Atividades e Operações Insalubres, e da outras providencias. Diário Oficial da União. Brasília, 2014.

ÇAKMAK, B. et al. Vibration and noise characteristics of flap type olive harvesters. Applied Ergonomics, United Kingdom, v. 42, p. 397-402, 2011.

CALVO, A. et al. Upper limb disorders and handarm vibration risks with hand-held olive beaters. International Journal of Industrial Ergonomics, Netherlands, v. 65, p. 36-45, 2018.

CAMPBELL, R.A.; JANKO, M.R.; HACKER, R. Hand-arm vibration syndrome: A rarely seen diagnosis. Journal of Vascular Surgery Cases and Innovative Techniques, United States, v. 3, p. 60-62, 2017.

AMERICAN CONFERENCE OF GOVERNMENTAL INDUSTRIAL HYGIENIST - ACGIH. TLVs e BEIs: baseado na documentação dos Limites de Exposição Ocupacional (TLVs) para Substâncias Químicas, Agentes Físicos e Índices Biológicos (BEIs). Tradução Associação Brasileira de Higienistas Ocupacionais ABHO, São Paulo, p. 298, 2018. 
FUNDAÇÃO JORGE DUPRAT FIGUEIREDO DE SEGURANÇA E MEDICINA DO TRABALHO FUNDACENTRO. Norma de Higiene Ocupacional - Procedimento Técnico. Avaliação da exposição ocupacional a vibrações em mãos e braços. NHO 10. São Paulo, p. 54, 2013.

CUNHA, J.P.B.; SILVA, F. M. da.; DIAS, R. E. B.A. Eficiência de Campo em Diferentes Operações Mecanizadas na Cafeicultura. Coffee Science, Lavras - MG, v. 11, n.1, p.76-86, 2016.

CUNHA. J. P. B et al. Viabilidade técnica e econômica de diferentes sistemas de colheita do café. Coffee Science, Lavras, v. 11, n. 3, p. 417 - 426, 2016.

EUROPEAN DIRECTIVE 2002/42/EC. Directive 2002/44/EC of the European Parliament ando of the Council of 25th June 2002 on the minimum health and safety requirements regarding the exposure to workers to the risks arising from physical agentes (vibration). The Official Journal of the European Communities, p. 13-19, 2002.

FERREIRA, D. F. Sisvar: a computer statistical analysis system. Ciência e Agrotecnologia (UFLA), Lavras - MG, v. 35, n. 6, p. 1039-1042, 2011.

FERRARY, D.A. et al. Dispositivo de mensuração de forças aplicado à sistemas de suspensão de roçadeiras laterais motorizadas: um estudo de caso. Brazilian Applied Science Review, Curitiba, v. 2, n. 3, p. 905919, 2018.

HAO, K.Y.; EAN, O. L.; RIPIN, Z. M. The design and development of suspended handles for reducing hand-arm vibration in petrol driven grass trimmer. International Journal of industrial Ergonomics, Netherlands, 41, p. 459-470, 2011.

HAJJAR, R. et al. Scaling up sustainability in commodity agriculture: Transferability of governance mechanisms across the coffee and cattle sectors in Brazil. Journal of Cleaner Production, United Kingdom, v. 206, p.124 -132, 2019.

HEAVER, C. et al. Hand-arm vibration syndrome: a common occupational hazard in industrialized countries. The Journal of Hand Surgery, United States, v. 36, p. 354-363, 2011.

INTERNATIONAL ORGANIZATION FOR STANDARDIZATION. ISO 5349-1: mechanizal vibration: measurement and evaluation of human exposure to hand-transmitted vibration: part 1: general requirements. Geneva, 2001.
INTERNATIONAL ORGANIZATION FOR STANDARDIZATION. ISO 8041: human response to vibration: measuring instrumentation. Geneva, 2005.

KUPPA S.K., LAL M. Dynamic Behavior Analysis of Grass Trimmer Using Finite Element Method. Research into Design for a Connected World. Singapore, v. 135, p. 563-573, 2019.

PATIL, S. S. Grass trimmer handle vibration reduction by imposing node method using vibration absorber. Noise and Vibration Worldwide, United Kingdom, v. 49, n. 2, p. 50-61, 2018.

POLETTOFILHO, J.A.; SANTOS, J.E. G.; POLETTO, H. M. C. Análise dos riscos físicos e ergonômicos em roçadora transversal motorizada. Revista Brasileira de Ergonomia, Rio de Janeiro - RJ, v.10, n.1, p.70-81, 2015.

REICHAMAN, D.R. Big Coffee in Brazil: Historical origins and implications for antropological political economy. Journal of latin American and Caribbean Antropology, United States, v. 23, n. 2, p. 241-261, 2018.

ROMANO, E. et al. Vibration transmission to the hand-arm system by means of portable olive beater: The effect of body mass. Chemical Engineering Transactions, Italy, v. 58, p. 97-102, 2017.

SANTINATO F. et al. Análise quali-quantitativa da operação de colheita mecanizada de café em duas safras. Coffee Science, Lavras - MG, v. 9, n. 4, p.495$505,2014$.

SILVA, J. A. R. et al. Occupational noise level in mechanized and semimecanized haverst of coffee fruits. Coffee Science, Lavras, v. 13, n. 4, p. 448 - 454, 2018.

SINGH, J.; KHAN, A. A.; Effect of coating over the handle of a drill machine on vibration transmissibility. Applied Ergonomics, United Kingdom, v.45, p.239246, 2014.

SCHUTZER, V. M. Avaliação de parâmetros ergonômicos: Vibração e ruído em roçadeiras laterias. 2018. 107p. Dissertação (Mestrado em Engenharia Mecânica) Universidade Estadual Paulista - UNESP, Bauru - SP, 2018.

WÓJCIK, K. The influence of the cutting attachment on vibrations emitted by brush cutters and grass trimmers. Leśne Prace Badawcze, Poland, v. 76, n. 4m p. 331340, 2015. 